* Corresponding author. E-mail address: claudio.cruz@ufrgs.br (C.E.F. Cruz).

\section{Confiscated Paroaria coronata and Saltator similis}

Short Title: Potential Health and Genetic Impacts in Releasing of Confiscated Songbirds.

Cláudio E. F. Cruz ${ }^{1,2^{*}}$, Gustavo R. Funkler ${ }^{1,3}$, André L. S. Zani ${ }^{4}$, Paulo G. C. Wagner ${ }^{1,5}$, Luciano N. Segura ${ }^{6}$, Inês Andretta ${ }^{7}$, Nelson J. R. Fagundes ${ }^{4,8}$

1 Centro de Estudos em Manejo de Aves Silvestres, Faculdade de Veterinária, Universidade Federal do Rio Grande do Sul, Porto Alegre, Rio Grande do Sul, Brasil.

2 Programa de Pós-Graduação em Ciências Veterinárias, Faculdade de Veterinária, Universidade Federal do Rio Grande do Sul, Porto Alegre, Rio Grande do Sul, Brasil.

${ }^{3}$ Laboratório Porto Belo. Porto Alegre, Rio Grande do Sul, Brasil.

4 Programa de Pós-Graduação em Genética e Biologia Molecular, Instituto de Biociências, Universidade Federal do Rio Grande do Sul, Porto Alegre, Rio Grande do Sul, Brasil.

5 Centro de Triagem de Animais Silvestres CETAS-Instituto Brasileiro do Meio Ambiente e dos Recursos Naturais Renováveis IBAMA. Porto Alegre, Rio Grande do Sul, Brasil.

${ }^{6}$ Universidad Nacional de La Plata. Museo de La Plata, Sección Ornitología, La Plata, Província de Buenos Aires, Argentina.

${ }^{7}$ Laboratório de Ensino Zootécnico. Faculdade de Agronomia, Universidade Federal do Rio Grande do Sul, Porto Alegre, Rio Grande do Sul, Brasil.

8 Programa de Pós-Graduação em Biologia Animal, Instituto de Biociências, Universidade Federal do Rio Grande do Sul, Porto Alegre, Rio Grande do Sul, Brasil.

\title{
Assessment of Potential Health and Genetic Impacts in Releasing
}




\section{Abstract}

Illegal capture and trade of wild birds has long been a threat to biodiversity.

Translocation - the release of individuals from one location into another - is a useful conservation tool in the management of species. However, both health (such as different pathogens) and adaptive (such as local adaptation), differences among populations must be taken into account, as both can impact the recipient population negatively. Here, we provide health and genetic information to support release planning for two of the most trafficked Brazilian wild bird species (Paroaria coronata and Saltator similis). We focused on two fundamental questions: Are there significant differences in pathogen load between wild and captive populations? Is there significant genetic structure among populations? In total, 223 free-living birds were captured, sampled, and released at the same site. Devices and live decoys characteristics were top factors influencing captures. We tested blood, feces, and oropharyngeal swabs from free-ranging $(n=101)$ and confiscated ( $\mathrm{n}=92)$ birds for Newcastle disease virus, Salmonella spp., and Mycoplasma gallisepticum. Genetic structure among populations was investigated using mtDNA in a subsample of these birds. We found no evidence for Newcastle disease virus and Salmonella spp. in seized and free-living birds from both species. However, seized $P$. coronata and $S$. similis may be potential sources of $M$. gallisepticum. We found significant but low genetic structure among populations occurring in different Biomes ( $\Phi_{C T}=0.26$ for $P$. coronata; $\Phi_{C T}=0.13$ for $S$. similis) and no significant structure among populations occurring in the Pampa Biome. These results suggest that while it may be important to screen seized birds for avian pathogens, genetic structure among populations seems to be of lesser concern when planning the release of seized songbirds in the wild.

\section{Introduction}


Illegal trade, along with poaching, habitat loss, and pollution, are top causes of wild bird decline in Brazil and in other developing countries that harbor a huge species diversity [1-4]. The illegal wildlife trade has increased dramatically over the past decade, along with enforcement efforts aimed at mitigating this threat [5]. For confiscated wild birds, despite the shortage of studies on the subject, current translocation guidelines include as an option the euthanasia of individuals belonging to species of low conservation value $[6,7]$. In part, this policy can be justified on the grounds that a) seized birds may harbor pathogens that will affect the wild population [8] and b) usually, seized birds come from an unknown parental population, and their release in another population may result in outbreeding depression $[9,10]$, resulting, in both cases, in a negative impact on the wild population. Health and genetic studies in wildlife species depend on direct capture for sampling free-ranging individuals and collecting relevant data to evaluate the sanitary and genetic risk of planned translocations. Ideally, such knowledge would allow the translocation of seized and rehabilitated birds to their most probable area of origin, with minimal health risks to the local populations and to the commercial flocks [5-8]. Unfortunately, both genetic and health information on the subject is scarce. Despite the myriad of methods and tools available, mist nets are globally recognized as the top capture method in biological studies [11-13] and are increasingly applied in association with bird lure techniques to improve efficiency, mostly through playback audio [14]. In this sense, the use of artificial $[15,16]$ or live decoys [17], although routinely and widely used in poaching, is only occasionally presented on scientific reports, albeit extensively disseminated in the virtual media.

In this study, we describe the methods for capturing and sampling wild Paroaria coronata (Red-crested Cardinal) and Saltator similis (Green-winged Saltator) — two of the most heavily trafficked Brazilian wild bird species, which are classified as of least 
concern on the IUCN red list [18]. Next, we generate sanitary and genetic data to answer two fundamental questions: Are there significant differences in pathogen load between wild and captive populations? Is there significant genetic structure among populations? Finally, we discuss the potential impacts of a translocation program of confiscated conspecifics for both species.

\section{Materials and Methods}

\section{Ethical statement}

This project (no. 23644) was approved by the Ethics Committee on the Use of Animals-UFRGS—and licensed by the Instituto Chico Mendes de Conservação da Biodiversidade (ICMBio), under the number 37567. Samples received from Argentina were registered under the export permit code EX-2019-12969382-APN-DNBI\#SGP.

\section{Sampled areas}

Sampling areas were selected to include representative areas of the species' usual distribution, mostly in Rio Grande do Sul state but also in strategic areas from the total species' distribution (Fig. 1, S1 Table). We captured S. similis in two different regions: Pampa and Atlantic Forest. Even though the Pampa is associated with open grasslands [19], we found S. similis always associated with forest paths as well as in the Atlantic Forest region. On its turns, we captured P. coronata in three different regions: Pampa, Atlantic Forest, and Chaco/Pantanal. In the Atlantic Forest, this species was associated with anthropic deforested paths. The Chaco/Pantanal region is characterized by savannah with a substantial forest component, especially in the Chaco, whose more humid portions are connected to the seasonally flooded Pantanal plain in Brazil [20-22]. Sample size was determined based on both pilot expeditions and on similar studies $[23,24]$. For the genetic 
analyses we also included sequences from the GenBank (Bolívia $n=1$, Boracéia $n=1$,

111 Corrientes $\mathrm{n}=2$, Mato Grosso $\mathrm{n}=1$ ) and an additional five $P$. coronata samples were received from the Buenos Aires area, Argentina.

Fig. 1. Geographical representation of sampled areas.

\section{Management of live decoys} parasites. Birds with positive samples were treated (anthelmintic and anticoccidial drugs). that failed 2-4 times consecutively were returned to CETAS. Seed mixtures, commercial rations, fruits, vegetables, arthropods, and minerals composed the birds' diets. During the capturing time (breeding season-August to February), the birds were kept in cages, and in the rest of the year, they were released in 12-24 $\mathrm{m}^{3}$ outdoor aviaries. Bath bowls, sunbath, and cage tray cleaning (sand bedding exchange) were performed every other day.

\section{Fieldwork}

Initially, we used mist nets and cages mounted with net-trapdoors (Fig. 2A) for 
demonstrated on the internet [25], and used next to the decoy's cage. All capturing processes were timed.

Fig. 2. Schematic representation of capturing devices. A: cage with live decoy Saltator similis, showing details of spring that closes the net-trapdoor (1), net-trapdoor (2), triggerperch (3), and metal hook holding the trigger-perch mounted and the net-trapdoor opened (4). B: loop with its parts numbered as the spring that pulls the fishing-rod which pulls the loop (5), fishing-rod (6), pin holding the trigger-perch mounted and fishing-rod (7), trigger-perch (8), brackets (nylon line folds) holding the loop open (9 and 10), and spring holding the trigger-perch up (11). C: Paroaria coronata captured in the loop.

Initial sampling was mostly conducted for studying genetic structure in both species. Blood samples $(0.1 \mathrm{ml})$ were obtained by right jugular vein puncture with an insulin syringe [26] and conserved in FTA cards for subsequent genetic applications. A second round of capture expeditions was conducted for obtaining most samples for the sanitary study, in which $0.1 \mathrm{ml}$ of blood (stored in Eppendorf tubes for serum separation), oropharyngeal swab, and feces (mostly after keeping the bird in a holding bag for up to $30 \mathrm{~min}$ ) were obtained. Such samples were tested for M. gallisepticum (MG) and Newcastle disease virus (NDV) serology, MG-PCR, and Salmonella spp. isolation, respectively. Samples for the sanitary studies were obtained from populations located up to $200 \mathrm{~km}$ from Porto Alegre, to make it possible to deliver them in the laboratory in the same day of collection. Samples were kept under refrigeration. The sampling period included the reproductive seasons of 2017, 2018, and 2019. After sampling, birds were 


\section{Sanitary tests}

The microbiological, serological, and molecular tests were performed at the Porto

Belo Laboratory, accredited by the Brazilian Ministry of Agriculture, Livestock, and Supply (Ministério da Agricultura, Pecuária e Abastecimento-MAPA) to perform official diagnostic tests within the National Plan of Avian Sanity (Plano Nacional de Sanidade Avícola-PNSA).

Anti-NDV antibodies were searched for in serum samples by the Hemagglutination Inhibition Test according to the SDA ordinance $n^{\circ} 182,08$ November 1994. Salmonella spp. detection followed the methods presented in SDA ordinance $\mathrm{n}^{\circ} 126$, as of November 03, 1995, after replacing BHI broth by buffered pebble water 1\%. Suspected colonies were confirmed and characterized with specific antisera (serum agglutination on blade) at the Fundação Oswaldo Cruz, according to World Health Association protocols [27]. For the detection of anti-MG antibodies, serum samples were tested by a rapid plate agglutination (RPA) test according to SDA ordinance $n^{\circ} 44$, as of November 08,2001 . A real-time polymerase chain reaction assay using a Taqman-labeled probe for the detection of M. gallisepticum (commercial kit MG-NewGene®) DNA [28] was applied, and the positive results were sent for confirmation with a Multiplex real-time PCR [29] at Simbios Biotechnology.

Serum samples from three $P$. coronata and three $S$. similis vaccinated against MG and NDV served as controls for validation of the MG-qPCR and NDV-HI. Serum samples from these birds were tested before and after vaccination to serve as negative and positive controls, respectively. Vaccination protocols included one ocular drop from live vaccines M. gallisepticum (MYCOVAX-TS-11, MERIAL, strain TS-11, P.400/17, V.02/18, November 11, 2017) and NDV (MERIAL, strain La Sota 004/16, ND1873, P.004/16, V.04/18, December 01, 2017), boosters with live vaccines for MG (BIOCAMP, Camp 
VacMG-F, P.006/2016, V.11/19, February 02, 2018) and NDV (BIOVET, New-Vacin,

La Sota, P.007/17, V.05/19, February 23, 2018). An additional booster included an oil

inactivated NDV (BIOVET, New-BRONK-VET, P.003/17, V.08/19, virus B1 La Sota,

minimum title before inactivation $10^{5,3} \mathrm{DIOE}_{50}$, March 23, 2018). Protocol was based on

a previous study on NDV vaccination of wild birds [30]. For the sanitary analyses, we

also included samples from birds confiscated from illegal handlers.

http://dx.doi.org/10.17504/protocols.io.bac3iayn. [PROTOCOL DOI].

192

\section{Genetic analysis}

In order to understand the genetic structure and diversity of $P$. coronata and $S$. similis, we compared individuals from the Pampa region, in which both species occur in relative abundance, with $P$. coronata individuals from the Chaco/Pantanal region and $S$. similis from the Atlantic Forest region. There were few samples of $P$. coronata from the Atlantic Forest and of $S$. similis from the Chaco/Pantanal because these are not major occurrence regions for these species. This strategy also allowed us to compare two regions of more similar vegetation patterns (Pampa vs. Chaco/Pantanal, in the case of $P$. coronata) with two regions with more different vegetation patterns (Pampa vs. Atlantic Forest, in the case of $S$. similis). Further information about the genetic sampling is given in S2 Table.

DNA was extracted from the blood in FTA cards using the PureLink Genomic DNA Mini Kit (Invitrogen), and the fragment of the mitochondrial gene NADH dehydrogenase subunit 2 (ND2) was amplified using the same PCR protocol for both species. The reaction was performed with concentrations of $20 \mathrm{ng} / \mu \mathrm{l}$ of DNA, 1x PCR Buffer (Invitrogen), $3.5 \mathrm{mM} \mathrm{MgCl} 2,0.2 \mathrm{mM}$ dNTPs, $0.2 \mathrm{pmol} / \mu 1$ of each primer, and $0.04 \mathrm{U} / \mu 1$ of Taq Platinum DNA Polymerase (Invitrogen). The primers used were MetL (described 
by Hailer et al. [31], sequence 5'-AAGCTATCGGGCCCATACCCG-3') and RND2A (this study, sequence 5'-CCTGAGTTGCATTYAGGGG-3'), and the PCR conditions were as follows: $94^{\circ} \mathrm{C}$ for $2 \mathrm{~min}, 35$ cycles of $94^{\circ} \mathrm{C}$ for $30 \mathrm{~s}, 59^{\circ} \mathrm{C}$ for $30 \mathrm{~s}, 72^{\circ} \mathrm{C}$ for 60 $\mathrm{s}$, and a final extension of $72^{\circ} \mathrm{C}$ for $8 \mathrm{~min}$. The amplification was confirmed through electrophoresis in a $1 \%$ agarose gel. The amplified products purified enzymatically with exonuclease I (GE Healthcare) and Sanger sequenced by ACTGene Inc., Brazil.

\section{Data analysis}

For field work data, descriptive variables for each capture were recorded in a spreadsheet (S1 Table). A principal component analysis was performed based on Gower's universal similarity index using Past v.3 (University of Oslo, Oslo, Norway. https://folk.uio.no/ohammer/past/). We used the Spearman correlation coefficient to relate the principal component with each of the studied variables. In addition, the association among categorical variables was studied using the Pearson chi-square test for association. These tests were conducted in Minitab v. 18 (State College, Pennsylvania, USA. http://www.minitab.com) using 0.05 as the significance threshold. Responses were also accessed using descriptive statistics.

For molecular data, DNA sequences were assembled and aligned in the software Geneious v.10.2.3 (https://www.geneious.com) and checked by eye in MEGA X v.10.0.0 [32]. We used DnaSP v.6.12.03 [33] to define all different haplotypes whose evolutionary relationships were represented using a Median-joining network [34], as estimated in the software PopART (http://www.popart.otago.ac.nz). Standard genetic diversity indices, including Tajima's D [35] and Fu's FS [36] neutrality tests were estimated using the program Arlequin v.3.5.2.2 [37]. We also used this program to quantify the level of genetic structure using both hierarchical and non-hierarchical Analysis of Molecular 
235 Variance (AMOVA) [38]. The hierarchical AMOVA was performed for each species 236 using the three collection regions (Pampa, Atlantic Forest, and Chaco/Pantanal). Non-

237 hierarchical AMOVA was performed only for the Pampa region to explicitly compare the level of structure in the same region using a comparable sample strategy for both species. Finally, to understand the past demography of both species, Bayesian Skylines plots (BSP) [39] were generated for the total population and the main occurrence regions of each one of them, using BEAST v.2.6.1 [40]. We used 10,000,000 MCMC steps, sampling every 1,000 steps and discarding the initial $10 \%$ of the sampling as burnin. We used a partition scheme allowing each codon position to have a different substitution model, which were estimated in MEGA X v.10 [32]. We checked sampling sufficiency of the MCMC and built the BSP in Tracer v.1.7.1 [41]. The molecular substitution rate for the ND2 gene was calculated as described previously [42], assuming the "calibration set 2" for a $45 \mathrm{~g}$ bird $[43,44]$.

\section{Results}

\section{Capturing birds in the wild}

In total, we performed 223 captures: 122 Saltators and 101 Cardinals (S1 Table). Net-trapdoors accounted for $36 \%$ of the captures, of which $97 \%$ were $S$. similis (Fig. 3). Catches using the loop method were $33 \%$ of the total, with a high prevalence of $P$. coronata $(89 \%)$. The mist nets provided comparable catches in both species under study, with $53 \%$ being $S$. similis.

Fig. 3. Frequency and duration of each capture according to bird species and capturing method. 
On average, it took 41.7 minutes ( \pm 1.69 minutes) for each bird capture, with similar values between species. Catches using the mist net were faster $(32.8 \pm 2.9$ minutes $)$ compared to captures performed with the net-trapdoor (43.1 \pm 1.9 minutes) or loop (48.5 \pm 3.6 minutes) methods. The mist net also accounted for $62 \%$ of the captures performed in less than 25 minutes, which correspond to the first quartile of the database. The principal component analyses show that capture method was the most important factor discriminating between $P$. coronata and S. similis captures (Fig. 4).

Fig. 4. Principal component analysis indicating captures (dots symbols) and the variables having the highest explanatory power (lines).

Characteristics of the decoy were associated to all studied variables in the captured

birds (Table 1), showing an important effect of the decoy in the capturing process. Some captures involved conspecific decoys. Male decoys accounted for $99 \%$ of the captures of $S$. similis, while the captures of $P$. coronata were well distributed among decoy sexes (couple: $42 \%$, male: $33 \%$, and female: $25 \%$ ). Among the female birds sampled, only $26 \%$ were captured using female decoys. A total of $60 \%$ of the female birds were captured using loop (almost exclusively P. coronata), while $75 \%$ of the male birds were captured using net-trapdoor or mist net, even though the low capture of female and young Saltators may bias these results. Decoys with a high ranking for dueling disposition and vocal performance (S3 Table) accounted for 96 and 98\% of the fastest captures (performed in less than 25 minutes), respectively. Seven birds $(\sim 3 \%)$ died due to capturing/sampling procedures. 
285 Table 1. Probability of association between characteristics of the captured bird (sex,

286 species, and age — or duration of the capture) with characteristics of the decoy or with the

287 method applied in the catch

288

\begin{tabular}{|c|c|c|c|c|}
\hline \multirow{2}{*}{ Decoy / Method } & \multicolumn{4}{|c|}{ Captured bird / Duration of capture } \\
\hline & Sex & Species & Age & Duration $^{2}$ \\
\hline Sex & $<0.001$ & $<0.001$ & 0.001 & 0.024 \\
\hline Species & $<0.001$ & $<0.001$ & 0.009 & $<\mathbf{0 . 0 0 1}$ \\
\hline Dueling disposition $^{3}$ & $<0.001$ & 0.047 & 0.015 & $\mathbf{0 . 0 3 7}$ \\
\hline Vocal. performance ${ }^{3}$ & 0.027 & $<0.001$ & 0.005 & 0.045 \\
\hline Method & $<0.001$ & $<\mathbf{0 . 0 0 1}$ & 0.095 & $<\mathbf{0 . 0 0 1}$ \\
\hline
\end{tabular}

290 Probabilities obtained in the Pearson chi-square test for association. Significant values

291 are shown in bold. ${ }^{2}$ Duration was ranked in four classes according to the quartiles. ${ }^{3}$ Each

292 decoy was ranked in three classes according to its behavior and vocalizations during captures (S3 Table). 
295

296

297

\section{Sanitary tests}

Data on the PNSA-associated tests performed on samples from both free-ranging and confiscated $P$. coronata and $S$. similis are presented in S4 Table. The serological study revealed no presence of antibodies against Newcastle disease, irrespective of the origin of the bird. Salmonella spp. isolation resulted in only one positive sample: $S$. enterica serovar Cerro from a free-ranging $P$. coronata. Two tests were applied for the detection of M. gallisepticum (MG). The RPA test indicated positive results for $25 \%$ of the samples from free-ranging birds, but none was confirmed by the PCR assay. On the other hand, seized birds showed positive results for MG in the RPA test in 53\% of the samples, which was reduced to $13 \%$ when samples were tested by PCR. Most disagreement between the tests were 'false-positive' results. Despite this variation, results obtained by the RPA method were highly correlated $(P<0.001)$ with the results obtained by PCR when assessed by a Pearson chi-square test.

\section{Genetic structure and diversity}

DNA sequence analysis resulted in an alignment of $977 \mathrm{bp}$ and $810 \mathrm{bp}$ for $P$. coronata and S. similis, respectively. All new sequences were deposited in GenBank (S2 Table). Genetic diversity indices for both species in all sampled regions are shown in Table 2. Overall, there was higher genetic diversity in S. similis than in P. coronata for both the whole sample as well as in the Pampa region. However, we found contrasting patterns between species when the two major regions of occurrence were compared. While for S. similis, the Pampa and Atlantic Forest have comparable levels of diversity, for $P$. coronata, the Pampa has only a fraction of the diversity contained in the Chaco/Pantanal region, which is also clear from the haplotype network (Fig. 5). For both species, the sample size in regions of minor occurrence (Atlantic Forest in the case of $P$. 
bioRxiv preprint doi: https://doi.org/10.1101/2020.03.10.985473; this version posted March 10, 2020. The copyright holder for this preprint (which was not certified by peer review) is the author/funder, who has granted bioRxiv a license to display the preprint in perpetuity. It is made available under aCC-BY 4.0 International license. characterization of the genetic diversity. 
Table 2. Standard genetic diversity indices for P. coronata and S. similis.

\begin{tabular}{|c|c|c|c|c|c|c|c|c|c|}
\hline & Source & Sample size & N Loc & $\begin{array}{c}\text { Segregating } \\
\text { sites }\end{array}$ & $\begin{array}{c}\mathrm{N} \\
\text { Haplot }\end{array}$ & $\begin{array}{l}\text { Haplotype } \\
\text { diversity }^{1}\end{array}$ & $\begin{array}{l}\text { Nucleotide } \\
\text { diversity }^{1}\end{array}$ & Tajima's $D^{2}$ & Fu's Fs ${ }^{2}$ \\
\hline & Pampa & 43 & 8 & 7 & 6 & $0.41(0.09)$ & $0.0006(0.0005)$ & -1.82 & -3.18 \\
\hline Paroaria & Chaco/Pantanal & 13 & 3 & 25 & 9 & $0.92(0.06)$ & $0.0066(0.0038)$ & -0.86 & -1.02 \\
\hline \multirow[t]{3}{*}{ coronata } & Atlantic Forest & 3 & 1 & 2 & 3 & $1.00(0.27)$ & $0.0014(0.0014)$ & 0.00 & -1.22 \\
\hline & Total & 59 & 12 & 30 & 14 & $0.60(0.07)$ & $0.0022(0.0014)$ & -2.17 & -4.76 \\
\hline & Pampa & 45 & 9 & 26 & 14 & $0.86(0.04)$ & $0.0058(0.0032)$ & -0.69 & -1.24 \\
\hline Saltator & Chaco/Pantanal & 3 & 2 & 2 & 2 & $0.67(0.31)$ & $0.0017(0.0017)$ & 0.00 & 1.06 \\
\hline \multirow[t]{2}{*}{ similis } & Atlantic Forest & 27 & 7 & 26 & 18 & $0.93(0.04)$ & $0.0042(0.0025)$ & -1.79 & -11.37 \\
\hline & Total & 75 & 18 & 43 & 27 & $0.90(0.03)$ & $0.0055(0.0031)$ & -1.59 & -10.65 \\
\hline
\end{tabular}

323 N Loc: N umber of localities; N Haplot: Number of haplotypes; ${ }^{1}$ Values in parenthesis are the standard deviation; ${ }^{2}$ Values in bold have a P-value $324<0.05$ for Tajima's D and $<0.02$ for Fu's Fs. 
Fig. 5. Median-joining network for the haplotypes of $P$. coronata (A) and S. similis (B).

The circle's size is proportional to the number of individuals in the sample with that haplotype. The transversal lines in the connectors represent the mutational steps.

The haplotype network for both species (Fig. 5) also suggests a relatively low degree of genetic structure among regions for both species. Indeed, when all regions are considered, $26.18 \%$ of the total genetic variance $\left(\Phi_{C T}=0.2618 ; P=0.040\right)$ occurs among regions for $P$. coronata, while for $S$. similis, this value is only $12.94 \%\left(\Phi_{C T}=0.1294\right.$; $P<0.001)$. On the other hand, most of the genetic variation occurs within populations: 65.17\% $\left(\Phi_{S T}=0.3483 ; P<0.001\right)$ and $82.72 \%\left(\Phi_{S T}=0.1728 ; P=0.011\right)$ for $P$. coronata and S. similis, respectively. The genetic structure among populations within regions corresponds to the remaining portion of genetic variance, but this value was not significant for both species $\left(\Phi_{S C}=0.1171 ; P=0.069\right.$ and $\Phi_{S C}=0.0499 ; P=0.090$ for $P$. coronata and S. similis, respectively). When only the Pampa region is considered, there is no significant genetic structure for either species $\left(\Phi_{S T}=-0.0510 ; P=0.923\right.$ and $\Phi_{S T}=0.0711 ; P=0.107$ for $P$. coronata and $S$. similis, respectively), corroborating the high general genetic homogeneity within regions shown in the previous analysis. in the Pampa region, in $S$. similis, it is exclusive from the Atlantic Forest region. The Bayesian Skyline analyses are congruent with these signals (Fig. 6). Population expansion in $P$. coronata seems to be more recent $(\sim 50,000$ years ago) and less dramatic than in $S$. similis, whose expansion seems to have occurred $\sim 350,000$ years ago. 
Fig. 6. Bayesian Skylines plots for P. coronata (A) and S. similis (B). The time scale is in thousands of years. The effective population size is multiplied by the generation time in the y-axis ( $\mathrm{Ne} x \mathrm{G})$. The colors indicate the region of the population considered: Total population—grey; Pampa—purple; Chaco/Pantanal—orange; Atlantic Forest—green.

\section{Discussion}

Our planet faces many biodiversity conservation challenges to fulfill the needs of an ever-growing human overpopulation $[3,4]$. Considering the limitation of financial resources for conservation, it is understandable that non-threatened species do not retain high conservation priority $[3,5,6]$. Indeed, neither the IUCN $[5,6]$ nor the Brazilian Ornithological Society [7] recommend translocation as a valuable conservation tool for non-threatened confiscated wild birds, as the cost of returning birds to the wild in a responsible manner can be prohibitive [6]. However, options other than humane killing of several thousand wild passerines deserve consistent investigation, since euthanizing a high numbers of wild birds annually $[45,46]$ involves ethical issues and may be incongruent with species conservation, especially in the long-term $[1,3]$. In fact, there has been some evidence that common species also can be susceptible to population declines [47]. The IUCN recognizes that returning confiscated animals of low conservation value to the wild may be valid, given that there are available resources and that translocation is undertaken in accordance with standard conservation guidelines, which should be based on genetic and sanitary information in addition to a number of other studies $[5,6]$. $S$.

371 similis and $P$. coronata are among the most trafficked passerine species in Brazil $372[45,46,48,49]$, which configures a legal and conservation challenge even if these species 
374 health [52] data from these species may help to substantiate decisions on

375 rehabilitation/release programs.

\section{Capturing and sampling wild birds}

In this study, after consecutive unsuccessful attempts at capturing live birds, we used live decoys in association with cages mounted with net-trapdoors, Indochinese loops, and mist-nets. Live conspecific decoys have long been among the poachers' practices for supplying illegal trade with wild birds [17]. This method simulates a territorial intrusion, which provides adequate capture opportunities, especially during the breeding season, since birds are prone to fight for defending their territories and are willing to mate [53]. Previously, baiting an area for a couple weeks to entice birds could facilitate the captures [12]; however, most of the capturing areas were visited only at the capture time.

Of the 223 catches, 83 were trapped in the net-trapdoors, of which almost all were $S$. similis, which readily engage in combat. On their turn, $P$. coronata are shyer, evaluating their opponents for long periods, hardly perching on unknown devices, and avoiding shaded areas that are suitable for mist netting. In this context, the use of loops camouflaged under a perch allowed the capture of this elusive species, even with the highest mean waiting-time recorded in the study. Loops were used to capture S. similis only in specific occasions, such as when it systematically perched in the same place and did not attack the decoy's cage. Mist nets provided comparable catches in both species under study (Fig. 3, Fig. 4).

The average target-catches per day was $\sim 2.5$, much lower than the 10.2 reported recently [14]. Unlike the aforementioned study, we spent considerable time on the road. 
399

400

401

402

403

404

405

406

407

408

409

410

411

412

413

414

415

416

417

the importance of team learning by practice $[54,55]$. For example, mist-netting masked by medium height vegetation or wood board fencing, under cloudy or shaded conditions, created additional opportunities for capturing open area birds such as P. coronata. Although with a greater effort for installing and linked to most of the non-target captures, the mist net was the fastest (33 minutes) capturing method for both species (Fig. 3).

During the three-year period, only four out of 24 birds that were selected as live decoys showed persistently high dueling disposition. The head down and retracted tuft of mute Cardinals and the ruffled feathers, low chirping, and open fallen wings of Saltators were submission behaviors observed under the free-ranging rival challenge. It has also been shown that in some bird species, males utilize vocal performance to evaluate competitors $[53,56]$. In our study, one specific $S$. similis decoy that whistled an obvious longer and louder terminal trill was associated with many catches $(\mathrm{n}=58)$. This individual likely elicited a wider territorial response to the song performance of this "intruder", similarly to what has been reported for Zonotrichia leucophrys males [56]. Thus, the efficiency of the decoy and, consequently, of the capture was associated with the level of the decoy's song performance or underlying health and vigor [53]. In most occasions in which decoys became mute and submissive, the free-living conspecific bird gave up the fight and left. However, as long as we had a replacement decoy, methods were effective and the target species were not captured, mostly when we couldn't find them.

Data on mortality rates in surveys involving bird capture are scarce and usually rely only on mist-netting $[57,58]$. While these studies report much lower mortality rates, they do not involve sampling of biological tissues. It is likely that most of the birds that died during collection, suffered from hemorrhages secondary to blood sampling. As an attempt to minimize such losses (S1 Table), blood collection was limited to $0.1 \mathrm{ml}$ per bird, instead of $0.2 \mathrm{ml}$ as we did at the beginning of the fieldwork. 


\section{Sanitary and health issues}

While there is a long list of diseases affecting wild birds [59], we decided to investigate only diseases addressed on the PNSA (i.e., Salmonellosis, mycoplasmosis, and Newcastle disease) due to its associated economical relevance [60] and because investigations about PNSA-associated pathogenic agents in wild passerines are rare.

Monitoring free-ranging wild birds have shown the same tendency [62].

Salmonella Enteritidis and Salmonella Typhimurium are, respectively, the serotypes most prevalent and most commonly associated with disease in wild birds [63]. been attributed to man/domestic animals-contaminated environments [64]. Indeed, previous studies estimated the prevalence of Salmonella in samples of wild birds, including in passerines confiscated from illegal traffic, at between 1-7\% [59,65-67]. In our sample, only one fecal sample $(0.7 \%)$ was positive for Salmonella cultivation and isolation, which is consistent with a previous study on Paroaria sp. in which Escherichia

444 This serovar has been linked to poultry feedstock and rations [68] and commercial laying farms [69] and has high prevalence among cattle herds [70], which was the case here, 
We found higher prevalence for MG using the RPA test compared to the qPCR assay for both free-living and seized birds, which was expected due to the limited accuracy of RPA [29]. MG-prevalence in poultry and wild birds has usually been higher under RPA than in other tests [71-73]. The qPCR-based estimate of $13 \%$ in $\mathrm{MG}$ prevalence in the seized group is comparable to what has been found in other avian hosts [74-76]. Similarly, the higher MG prevalence in seized birds probably reflects the poor hygiene and stressful conditions to which these birds are subjected [59]. Even though MG exposure has been reported for wild birds [71,74,77], the lack of qPCR-based positive samples for MG is in agreement with another Brazilian study that sampled wild birds in poultry farms surrounded by forest remnants [78]. Even though none of the positive individuals in our sample showed any clinical evidence of infection, differential MGsusceptibility across bird species has been observed after experimental infections that resulted in both clinical and subclinical symptoms [79], which also occurred in wild birds $[74,77,80]$. Disease outbreaks in free-ranging and captive wild bird have been recorded, suggesting a potential reservoir for the pathogen in nature [81-83], reinforcing the need of a reliable MG assay for elucidating the role of $\mathrm{MG}$ in populations of wild birds.

Genetic diversity, structure, and implications of outbreeding depression

The two species revealed different levels of genetic diversity and different evolutionary demographic histories. S. similis had overall higher genetic diversity, a more ancient population expansion restricted to the populations in the Atlantic Forest (while the Pampa population remained constant), and similar levels of diversity between the Pampa and the Atlantic Forest, its major regions of occurrence. On its turn, P. coronata 
472 the Pampa (while the Chaco/Pantanal population remained constant), and lower diversity

473 in the Pampa compared to the Chaco/Pantanal region (Table 2, Fig. 5, Fig. 6).

Southern South America $[84,85]$, . coronata from the Chaco/Pantanal had a high diversity at both the haplotype and nucleotide level. Even though some population of

477 Gubernatrix cristata, a highly endangered Thraupidae, had higher nucleotide diversity 478 values [84], this study used the mtDNA control region (mtDNA-CR) as a genetic marker, which evolves faster than ND2 [86]. On the other hand, P. coronata from the Pampa had a low diversity at both indices. This may indicate that the population inhabiting the Pampa biome is a recent offshoot from the Chaco/Pantanal region, which may have acted as a large source population for this species. This is compatible with the exclusive signal of population expansion in the Pampa around 50,000 years ago (Fig. 6), as population growth is usually expected in refuge areas [87]. and other associated humid forests, $S$. similis revealed a high diversity both in the Pampa as well as in the Atlantic Forest regions. Considering studies that used mtDNA coding genes only [88-95], S. similis from the Atlantic Forest had the highest value for a forestassociated species (only lower than $P$. coronata from the Chaco/Pantanal), while the populations are also among the highest for passerines associated with the Atlantic Forest [88-95]. The exclusive signal of an ancient population expansion for $S$. similis in the Atlantic Forest region but not in the Pampa is curious. First, most studies that detected a population expansion in specific populations or phylogroups suggest much more recent timescales (similar to P. coronata) $[90,92,94,96]$. The two exceptions that report older 
$497150,000-300,000$ years ago. The high genetic diversity and lack of a signal of population expansion in the Pampa is intriguing. It is unlikely that the Pampa behaved as a refuge area for this species, which is strongly associated with humid forests northern to the Pampa region. Besides, the Atlantic Forest has higher genetic diversity than the Pampa, which is not compatible with a scenario in which the population in a refuge - the Pampa - occupies the Atlantic Forest and expands thereafter. Taken together, the lack of strong genetic structure between these populations may indicate that the Pampa was occupied in consequence of the population expansion in the Atlantic Forest but subsequently lost genetic diversity, which eroded the signal of an ancient expansion.

We also found a very weak genetic structure for both $P$. coronata and $S$. similis

(Fig. 6). In the Pampa and associated dry forests, both Gubernatrix cristata [84] and Phytotoma rutila [85] showed stronger structure among habitats $\left(\Phi_{S T} \sim 0.45\right)$. For forest species, most studies reported the presence of strongly differentiated phylogroups either between different habitats or across the Atlantic Forest [88-90,93-99]. Again, the exceptions are Schiffornis virescens [91] and Basileuterus leucoblepharus [92], which showed no phylogeographic breaks across its distribution in the Atlantic Forest. The lack

513 of genetic structure in $S$. similis is corroborated by a study that, based on nine microsatellite (SSR) loci, reported that only $0.1 \%$ of the total genetic variation occurred 515 among populations distributed in different Brazilian biomes (Atlantic Forest, Cerrado, 516 Caatinga and ecotones between these) [50]. Similarly, even though no study has 517 characterized $P$. coronata populations for SSR variation, the closely related species $P$. 518 dominicana, which occurs in the Brazilian northeast, showed that only $3 \%$ of the total genetic variation occurred among populations. [50]. Thus, the high genetic connectivity among populations does not seem to be an artifact from using only mtDNA. 
The shallow population differentiation found in this study may have important

522

523

consequences for conservation policies. Even though genetic distance is not a good predictor of outbreeding depression [100], outbreeding depression requires different genetic adaptations to local environments that will be broken by crossing individuals from exogenous populations $[9,10,101]$. The high historic genetic connectivity across populations of both species suggests that the overall risk of outbreeding depression is low [101].

\section{Concluding remarks}

The management of birds seized from illegal traffic is a complex and difficult question; Even though the recommendation for euthanizing individuals belonging to species of low conservation value may be justified [6,7], could new information for focal species reduce the perceived risk of translocation to the point that this could become a standard practice? In this study, we showed that it may be feasible to screen seized birds for several pathogens and that while the overall prevalence rates are low, the risk of disease transmission during bird management or after release in natural environments justifies a systematic sanitary screening. In addition, applying an adequate quarantine period for all seized birds seems to be both feasible and indispensable for maintaining proper sanitary conditions of the wild bird populations in translocation/reintroduction initiatives. Furthermore, systematic pathological investigations on confiscated birds dying during the quarantine/rehabilitation processes may point to additional relevant conditions to be included on the health screening.

The shallow genetic structure found for both species suggest that the overall risk of outbreeding depression following translocation is low. Yet, additional criteria could be used to choose an area for translocating individuals. For example, using different regional 
546 vocal "dialects" as a proxy for the original parental population of an individual [102].

547 Vocal plasticity exhibited by several species may indicate that, for the undetermined

548 cases, reintroduced birds will be able to adapt to their release sites [102]. Another eventual

549 strategy could be releasing the birds close to the apprehension site. Conservationist

550 policymakers should consider when translocating seized individuals into wild populations

551 could represent a safe and useful strategy for maintaining large and healthy wild 552 populations for species highly targeted for illegal trade, irrespective of their conservation 553 status.

\section{Acknowledgements}

We are grateful to CMPC Celulose Riograndense Ltda. for financial support and

557 to the land owners who allowed access to their property to conduct fieldwork, especially 558 to Biesdorf Family (Eldorado do Sul), Helena and Edegardo Velho, Ronaldo Bicca, 559 André Carvalho (Mostardas), Paulo and Fernando Menezes (Cachoeira do Sul), Ione 560 Ferreira, César Silveira (Encruzilhada do Sul), Teófilo Garcia (Santo Antônio das 561 Missões), Ivan Pereira, Arcídio Trojan (Alegrete), Lívia Quoos, Mauro Amaral (Rosário 562 do Sul), Ênio Brito (Santa Vitória do Palmar), and Gildomar Monte (Rio Grande), but 563 also to André Thuronyi, Guilherme Arruda, Denise Senna (Poconé), Débora Murgol 564 (Santo Antônio do Pinhal) and João Venturini (Corumbá). We thank Armando Garcia, 565 Marcelo Maronna, Cristina Trein, and João Almeida for connecting us with land owners.

566 We are also grateful to ICMBio and IBAMA for providing us the study licenses, and to 567 the managers of the conservation areas Edenice Souza (Floresta Nacional de São 568 Francisco de Paula), and Soraya Ribeiro (Parque Natural Morro do Osso). We also thank 569 Fabiana Quoos Mayer for technical assistance and Raquel Hohendorf, Diógenes 
571 Fundação de Apoio da Universidade Federal do Rio Grande do Sul for administrative

572 support

573

574 References

575 1. Collar NJ, Long AJ, Jaime PRG. Birds and people: bonds in a timeless journey. 1st ed. Cambridge, UK: Birdlife International; 2007.

2. Alves RRN, Lima, JRF, Araujo HFP. The live bird trade in Brazil and its conservation implications: an overview. Bird Conserv Int. 2013; 23: 53-65.

3. Sodhi NS, Ehrlich PR. Conservation biology for all. 1st ed. New York: Oxford University Press Inc.; 2010.

4. Fitzpatrick JW, Rodewald AD. Bird conservation. In: Lovette IJ, Fitzpatrck JW, editors. Handbook of bird biology, 3rd ed. The Cornell Lab of Ornithology: Wiley; 2016. pp. 579-639.

5. IUCN. Guidelines for the Management of Confiscated Live Organisms. Maddison N, editor. Gland, Switzerland: IUCN; 2019. pp. 38. https://doi.org/10.2305/IUCN.CH.2019.03.en.

6. IUCN. Guidelines for the Placement of confiscated Animals. Gland, Switzerland: IUCN; 2000.

7. Efe MA, Martins-Ferreira C, Olmos F, Mohr LV, Silveira LF. Diretrizes da Sociedade Brasileira de Ornitologia para a destinação de aves silvestres provenientes do tráfico e cativeiro. Rev Bras Ornitol. 2006; 14: 67-72.

8. Kock RA, Woodford MH, Rossiter PB. Disease risks associated with the translocation of wildlife. Rev Sci Tech Off Int Epizoot. 2010; 29: 329-350. https://doi.org/10.20506/rst.29.2.1980.

9. Edmands S. Between a rock and a hard place: evaluating the relative risks of inbreeding and outbreeding for conservation and management. Mol Ecol. 2007; 16: 463-475. 
10. Whitlock R, Stewart GB, Goodman SJ, Piertney SB, Butlin RK, Pullin AS, et al. A systematic review of phenotypic responses to between-population outbreeding. Environ Evid. 2013; 2: 13.

11. Schemnitz SD, Batcheller GR, Lovallo MJ, White HB, Fall MW. Capturing and handling wild animals. In: Silvy NJ, editor, The wildlife technique manual. Johns Hopkins University Press; 2009. pp. 232-269. Available from: https://digitalcommons.unl.edu/icwdm usdanwrc.

12. FAO. Wild birds and avian influenza. An introduction to applied field research and disease sampling techniques. In: Whitwoth D, Newman S, Mundkur T, Harris P, editors. FAO animal production and health manual; 2007. pp. 33-50. Available from: www.fao.org/avianflu.

13. Ross AL. Capturando aves. In: Matter SV, Straube FC, Accordi IA, Piacentini VQ, Cândido-JR JF, editors. Ornitologia e conservação-Ciência aplicada, técnicas de pesquisa e levantamento. Technical Books Editora; 2010. pp. 79-104.

14. Ndlovu M. Birdcall lures improve passerine mist-net captures at a sub-tropical African savanna. Plos One. 2018; e0199595. https://doi.org/10.1371/journal.pone.0199595.

15. Crozier GE, Gawlik DE. The use of decoys as a research tool for attracting wading birds. J Field Ornithol. 2003; 74: 53-58.

16. Smith J. Decoy: how fake birds aid real research. 2014. Available from: https://blog.nature.org/science/2014/10/30/decoy-fake-birds-real-research-video.

17. Bezerra DMM, Araújo HFP, Alves RRN. Captura de aves silvestres no semiárido brasileiro: técnicas cinegéticas e implicações para conservação. Trop Conserv Sci. 2012; 5: 50-66.

18. IUCN. The IUCN red list of threatened species. Cited 2019 Match 10. Available from: https://www.iucnredlist.org/species. 
19. Overbeck GE, Müller SC, Fidelis A, Pfadenhauer J, Pillar VD, Blanco CC, et al. Brazil's neglected biome: The South Brazilian Campos. Perspect Plant Ecol Syst. 2007; 9: 101-116.

20. Adámoli J. Bases para uma política comum de conservação das terras úmidas do Pantanal e do Chaco. Anais do III Simpósio sobre recursos naturais e sócioeconômicos do Pantanal. Centro de Pesquisa Agropecuária do Pantanal; 2000. pp. 1-15.

21. Silva MP, Mauro R, Mourão G, Coutinho M. Distribuição e quantificação de classes de vegetação do Pantanal através de levantamento aéreo. Rev Bras Bot. 2000; 23: 143-152.

22. Freitas TG, Souza CS, Aoki C, Arakaki LMM, Stefanello TH, Sartori ALB, et al. Flora of Brazilian humid Chaco: composition and reproductive phenology. Check List. 2013; 9: 973-979.

23. Castro MS, Recco-Pimentel SM, Rocha GT. Karyotypic characterization of Ramphastidae (Piciformes, Aves). Gen Mol Biol. 2002; 25: 147-150.

24. Nogueira DM, Souza LM, Goldschmidt B, Silva CP, Monsores DW. The karyotype of the critically endangered Lear's macaw, Anodorhynchus leari Bonaparte 1856 (Aves, Psittaciformes). Gen Mol Biol. 2006; 29: 656-658.

25. Ravuth Natural Life. [video]. Cited 2017 July 4. Available from: http://www.youtube.com/watch?v=X8f6FuvdQpM.

26. Friend M, Toweill DE, Brownell RL, Nettles VF, Davis DS, Foreyt WJ. Section 1-Chapter 6: Guidelines for proper care and use of wildlife in field research. In: Friend M, Franson JC, editors. Field manual of wildlife diseases: general field procedures and diseases of birds; 1999. pp. 53-72. Cited 2018 April 12. Available from: https://pubs.usgs.gov/itr/1999/field_manual_of_wildlife_diseases.pdf

27. Kauffmann F, Le Minor L. Kauffmann-White Scheme. In: Patrick AD, Grimont PA, François-Xavier W, editors. Antigenic formulae of Salmonella Serovars. 9th ed. Paris, France: WHO (World Health Organization) and Institute Pasteur; 2007. Available from: https://www.pasteur.fr/sites/default/files/veng_0.pdf. 
653

654

655

656

657

658

659

660

661

662

663

664

665

666

667

668

669

670

671

672

673

674

675

676

677

678

28. Callison SA, Riblet SM, Sun S, Ikuta N, Hilt D, Leiting V, Kleven SH, Suarez DL, García M. Development and validation of a real-time Taqman polymerase chain reaction assay for the detection of Mycoplasma gallisepticum in naturally infected birds. Avian Dis. 2006; 50: 537-544.

29. Fraga AP, Vargas TD, Ikuta N, Fonseca ASK, Celmer AJ, Marques EK, Lunge VR. A Multiplex real-time PCR for detection of Mycoplasma gallisepticum and Mycoplasma synoviae in clinical samples from Brazilian commercial flocks. Bras J Microbiol. 2013; 44: 505-510.

30. Gomes CWC, Funkler GR, Andretta I, Gonçalves MO, Santos HF, Cruz CEF. Newcastle disease vaccination in captive-bred wild birds. Trop Anim Health Prod. 2018; 50: 1349-1353.

31. Hailer F, Schreiber E, Miller J, Levin I, Parker P, Chesser R et al. Long-term isolation of a highly mobile seabird on the Galapagos. Proc R Soc B. 2010; 278: $817-825$.

32. Kumar S, Stecher G, Li M, Knyaz C, Tamura K. MEGA X: Molecular Evolutionary Genetics Analysis across Computing Platforms. Mol Biol Evol. 2018; 35: 1547-1549.

33. Rozas J, Ferrer-Mata A, Sánchez-DelBarrio J, Guirao-Rico S, Librado P, RamosOnsins S et al. DnaSP 6: DNA Sequence Polymorphism Analysis of Large Data Sets. Mol Biol Evol. 2017; 34: 3299-3302.

34. Bandelt H, Forster P, Rohl A. Median-joining networks for inferring intraspecific phylogenies. Mol Biol Evol. 1999; 16: 37-48.

35. Tajima F. Statistical method for testing the neutral mutation hypothesis by DNA polymorphism. Genetics. 1989; 123: 585-595.

36. Fu YX. Statistical tests of neutrality of mutations against population growth, hitchhiking and background selection. Genetics. 1997; 147: 915-925. 
37. Excoffier L, Lischer HEL. Arlequin suite ver 3.5: a new series of programs to perform population genetics analyses under Linux and Windows. Mol Ecol Resour. 2010; 10: 564-567.

38. Excoffier L, Smouse PE, Quattro JM (1992) Analysis of molecular variance inferred from metric distances among DNA haplotypes: Application to human mitochondrial DNA restriction data. Genetics. 1992; 131: 479-491.

39. Drummond A, Rambaut A, Shapiro B, Pybus O. Bayesian Coalescent Inference of Past Population Dynamics from Molecular Sequences. Mol Biol Evol. 2005; 22: 1185-1192.

40. Bouckaert R, Vaughan T, Barido-Sottani J, Duchêne S, Fourment $M$, Gavryushkina A et al. BEAST 2.5: An advanced software platform for Bayesian evolutionary analysis. PLOS Comput Biol. 2019; 15: e1006650.

41. Rambaut A, Drummond A, Xie D, Baele G, Suchard M. Posterior Summarization in Bayesian Phylogenetics Using Tracer 1.7. Syst Biol. 2018; 67: 901-904.

42. Nabholz B, Lanfear R, Fuchs J. Body mass-corrected molecular rate for bird mitochondrial DNA. Mol Ecol. 2016; 25: 4438-4449.

43. de Faria IP, de Paula WS. Body masses of birds from Atlantic forest region, southeastern Brazil. Ornitol Neotrop. 2008; 19: 599-606.

44. Segura LN, Mahler B, Berkunsky I, Reboreda JC. Nesting biology of the Redcrested Cardinal (Paroaria coronata) in south temperate forests of central Argentina. Wilson J Ornithol. 2015; 127: 249-258.

45. RENCTAS. $1^{\circ}$ Relatório Nacional sobre o Tráfico de Fauna Silvestre; 2002. Available from: http://www.renctas.org.br/wpcontent/uploads/2014/02/REL_RENCTAS_pt_final.pdf

46. IBAMA. Relatório Técnico CETAS 2002-2014. Brasília, Brasil; 2016. Available from: http://www.consultaesic.cgu.gov.br/busca/dados/Lists/Pedido/Attachments/53910 9/RESPOSTA_PEDIDO_an.pdf 
47. Lindenmayer DB, Wood JT, McBurney L, MacGregor C, Youngentob K, Banks SC. How to make a common species rare: a case against conservation complacency. Biol Conserv. 2011; 144: 1663-1672.

48. Araújo ACB, Behr ER, Longhi SJ, Menezes PTS, Kanieski MR. Diagnóstico sobre a fauna apreendida e entregue espontaneamente na região central do Rio Grande do Sul, Brasil. Rev Bras Biocienc. 2010; 8: 279-284.

49. Viana IR, Zocche JJ. Avifauna apreendida no extremo sul catarinense: apreensões feitas durante oito anos de fiscalização e combate à captura de aves silvestres. Braz J Biosci. 2013; 11: 395-404.

50. Ferreira JM. Contribuição da genética de populações à investigação sobre o tráfico de fauna no Brasil: desenvolvimento de microssatélites e análise da estrutura genética em Paroaria dominicana e Saltator similis (Aves: Passeriformes: Thraupidae). Doctoral dissertation, Instituto de Biociências da Universidade de São Paulo. 2012. DOI. 10.11606/T.41.2012.tde-17122012-200300. Available from: https://teses.usp.br/teses/disponiveis/41/41131/tde-17122012200300/publico/Juliana Ferreira.pdf

51. Ferreira JM, Burnham-Curtis M, Schunck F, Rocha M, Myiaki CY, Silveira LF, et al. Development of novel polymorphic microsatellite markers for four bird species exploited by the illegal wildlife trade in Brazil. Conserv Genet Resour. 2015; 7: 435-436.

52. Godoy SN, Matushima ER. A survey of diseases in passeriform birds obtained from illegal wildlife trade in São Paulo City, Brazil. J Avian Med Surg. 2010; 24: 199-209.

53. Byers BE, Kroodsma DE. Avian vocal behavior. In: Lovette IJ, Fitzpatrck JW, editors. Handbook of bird biology. 3rd ed. The Cornell Lab of Ornithology: Wiley; 2016. pp. 355-405.

54. Ralph CJ, Dunn E, Peach WJ, Handel CM. Recommendations for the use of mist nets for inventory and monitoring of bird populations. Stud Avian Biol. 2004; 29: 187-196. 
55. Martin SG. A technique for capturing nesting grassland birds with mist nets. Bird Banding. 1968; 40: 233-237.

56. Phillips GN, Derryberry EP. Vocal performance is a salient signal for male-male competition in White-crowned Sparrows. The Auk. 2017; 134: 564-574.

57. Spotswood EN, Goodman KR, Carlisle J, Cormier RL, Humple DH, Rousseau J, et al. How safe is mist-netting? Evaluating the risk of injury and mortality to birds. Methods Ecol Evol. 2012; 3: 29-38.

58. Clewley GD, Robinson RA, Clark JA. Estimating mortality rates among passerines caught for ringing with mist nets using data from previously ringed birds. Ecol Evol. 2018; 8: 5164-5172.

59. Thomas NJ, Hunter DB, Atkinson CT. Infectious diseases of wild birds. 1st ed. Oxford, UK: Blackwell Publishing; 2007.

60. MAPA. Ministério da Agricultura, Pecuária e Abastecimento. Available from: http://www.agricultura.gov.br/assuntos/sanidade-animal-e-vegetal/saudeanimal/programas-de-saude-animal/sanidade-avicola

61. Oliveira-Júnior JG, Portz C, Loureiro BO, Schiavo PA, Fedullo LPL, Mazur C, et al. Vírus da doença de Newcastle em aves não vacinadas no estado do Rio de Janeiro. Cienc Rural. 2003; 33: 381-383.

62. Camenisch G, Bandli R, Hoop R. Monitoring of wild birds for Newcastle disease virus in Switzerland using real time RT-PCR. J Wildl Dis. 2008; 44: 772-776.

63. Benskin CM, Wilson K, Jones K, Hartley R. Bacterial pathogens in wild birds: a review of the frequency and effects of infection. Biol Rev. 2009; 84: 349-373.

64. Abulreesh HH, Goulder R, Scott GW. Wild birds and human pathogens in the context of ringing and migration. Ringing Migr. 2007; 23: 193-200. Available from: https://doi.org/10.1080/03078698.2007.9674363.

65. Tizard I. Salmonellosis in wild birds. Semin Avian Exotic Pet Med. 2004; 13: 5066. 
66. Braconaro P, Saidenberg AB, Benite NR, Zuniga E, Silva AM, Sanches TC, et al. Detection of bacteria and fungi and assessment of the molecular aspects and resistance of Escherichia coli isolated from confiscated passerines intended for reintroduction programs. Microb Pathog. 2015; 88: 65-72.

67. Cunha MPV, Guimarães MB, Davies YM, Milanelo L, Knöbl T. Bactérias gramnegativas em cardeais (Paroaria coronata e Paroaria dominicana) apreendidos no tráfico de animais silvestres. Braz J Vet Res Anim Sci. 2016; 53: 107-111.

68. Hoffer E, Silva-Filho SJ, Reis EMF. Sorovares de Salmonella isolados de matérias-primas e de ração para aves no Brasil. Pesq Vet Bras. 1998; 18: 21-27.

69. Moraes DMC. Investigação bacteriológica e molecular de Salmonella spp. em granjas de postura comercial. Doctoral dissertation, Universidade Federal de Goiás, 2014. Available from: https://ppgca.evz.ufg.br/up/67/o/Tese_Dunya_Mara_Cardoso_Moraes.pdf

70. Cummings KJ, Warnick LD, Elton M, Rodriguez-Rivera LD, Siler JD, Wright EM, et al. Salmonella enterica Serotype Cerro among dairy cattle in New York: an emerging pathogen? Foodborne Pathog Dis. 2010; 7: 659-665.

71. Fritz BA, Thomas CB, Yuill TM. Serological and microbiological survey of Mycoplasma gallisepticum in wild turkeys (Meleagris gallopavo) from six western states. J Wildl Dis. 1992; 28: 10-20.

72. Júnior AM, Taunde P, Zandamela AF, Junior AP, Chilundo A, Costa R, et al. Serological screening suggests extensive presence of Mycoplasma gallisepticum and Mycoplasma synoviae in backyard chickens in Southern Mozambique. J Vet Med. 2017; http://dx.doi.org/10.1155/2017/2743187.

73. Teixeira VCM, Baptista DQ, Carlos FC, Menezes WR, José DS, Barreto ML, et al. Situação epidemiológica da micoplasmose aviária no Estado do Rio de Janeiro. Rev Bras Vet Med. 2015; 34: 379-385.

74. Dhondt AA, DeCoste J, Ley DH, Hochachka WM. Diverse wild bird host range of Mycoplasma gallisepticum in Eastern North America. Plos One. 2014; e103553. https://doi.org/10.1371/journal.pone.0103553. 
75. Hartup BK, Kollias GV, Ley DH. Mycoplasmal conjunctivitis in songbirds from New York. J Wildl Dis. 2000; 36: 257-264.

76. Carvalho AM, Andrade MA, Linhares GF, Jaime VS. Pesquisa de Mycoplasma em aves da família Psittacidae mantidas em diferentes cativeiros no Brasil Central. Pesq Vet Bras. 2017; 37: 1159-1164.

77. Michiels T, Welby S, Vanrobaeys M, Quinet C, Rouffaer L, Lens L, et al. Prevalence of Mycoplasma gallisepticum and Mycoplasma synoviae in commercial poultry, racing pigeons, and wild birds in Belgium. Avian Pathol. 2016; 45: 244 252.

78. Guimarães MB, Hurtado R, Bello CP, Vanstreels RET, Ferreira AJP. Surveillance for Newcastle Disease Virus, Avian Influenza Virus and Mycoplasma gallisepticum in wild birds near commercial poultry farms surrounded by Atlantic rainforest remnants, Southeastern Brazil. Braz J Poult Sci. 2016; 18: 387-394.

79. Farmer KL, Hill GE, Roberts SR. Susceptibility of wild songbirds to the house finch strain of Mycoplasma gallisepticum. J Wildl Dis. 2005; 41: 317-325.

80. Hidasi HW. Detecção de Salmonella sp., Mycoplasma spp., Escherichia coli de aves sinantrópicas da região metropolitana de Goiânia-Goiás. Doctoral dissertation, Escola de Veterinária e Zootecnia da Universidade Federal de Goiás. 2013. https://ppgca.evz.ufg.br/up/67/o/Tese2013 Hilari Hidasi.pdf

81. Fischer JR, Stallknecht DE, Luttrell P, Dhondt AA, Converse KA. Mycoplasmal conjunctivitis in wild songbirds: the spread of a new contagious disease in a mobile host population. Emerg Infect Dis. 1997; 3: 69-72.

82. Pennycott TW, Ross HM, McLaren IM, Park A, Hopkins GF, Foster G. Causes of death of wild birds of the family Fringillidae in Britain. Vet Rec. 1998; 143: 155158.

83. Oliveira LGS, Boabaid FM, Lorenzett MP, Rolim V, Santos HF, Driemeier D, et al. Outbreaks of mycoplasmosis and histomoniasis in a southern Brazilian flock of ornamental birds. Acta Sci Vet. 2017; 45: 200. Available from: 
84. Domínguez M, Tiedemann R, Reboreda J, Segura L, Tittarelli F, Mahler B. Genetic structure reveals management units for the yellow cardinal (Gubernatrix cristata), endangered by habitat loss and illegal trapping. Conserv Genet. 2017; 18 : $1131-1140$.

85. Rodríguez-Cajarville M, Calderón L, Tubaro P, Cabanne G. Body size and genetic variation in the White-tipped Plantcutter (Phytotoma rutila: Cotingidae) suggest ecological divergence across the Chaco-Andes dry forest belt. J Ornithol. 2019; 160: 947-961.

86. Barker F, Benesh M, Vandergon A, Lanyon S. Contrasting Evolutionary Dynamics and Information Content of the Avian Mitochondrial Control Region and ND2 Gene. PLOS ONE. 2012; 7: e46403. Genetic Diversity in the Brazilian Atlantic Forest Hotspot. Science. 2009; 323: 785-789.

88. Cabanne G, Dhorta F, Sari E, Santos F, Miyaki C. Nuclear and mitochondrial phylogeography of the Atlantic forest endemic Xiphorhynchus fuscus (Aves: Dendrocolaptidae): Biogeography and systematics implications. Mol Phylogenetics Evol. 2008; 49: 760-773.

90. Maldonado-Coelho M. Climatic oscillations shape the phylogeographical structure of Atlantic Forest fire-eye antbirds (Aves: Thamnophilidae). Biol J Linn Soc. 2012; 105: 900-924. demographic expansion, low diversity and lack of phylogeographic structure in the 
Atlantic forest endemic Greenish Schiffornis Schiffornis virescens (Aves: Tityridae). J Ornithol. 2012; 154: 371-384.

92. Batalha-Filho H, Cabanne G, Miyaki C. Phylogeography of an Atlantic forest passerine reveals demographic stability through the last glacial maximum. Mol Phylogenetics Evol. 2012; 65: 892-902.

93. Amaral F, Albers P, Edwards S, Miyaki C. Multilocus tests of Pleistocene refugia and ancient divergence in a pair of Atlantic Forest antbirds (Myrmeciza). Mol Ecol. 2013; 22: 3996-4013.

94. Batalha-Filho H, Miyaki C. Late Pleistocene divergence and postglacial expansion in the Brazilian Atlantic Forest: multilocus phylogeography of Rhopias gularis (Aves: Passeriformes). J Zool Syst Evol Res. 2016; 54: 137-147.

95. Trujillo-Arias N, Dantas G, Arbeláez-Cortés E, Naoki K, Gómez M, Santos F et al. The niche and phylogeography of a passerine reveal the history of biological diversification between the Andean and the Atlantic forests. Mol Phylogenetics Evol. 2017; 112: 107-121.

96. Cabanne G, Santos F, Miyaki C. Phylogeography of Xiphorhynchus fuscus (Passeriformes, Dendrocolaptidae): vicariance and recent demographic expansion in southern Atlantic forest. Biol J Linn Soc. 2007; 91: 73-84.

97. Cabanne G, d'Horta F, Meyer D, Silva J, Miyaki C. Evolution of Dendrocolaptes platyrostris (Aves: Furnariidae) between the South American open vegetation corridor and the Atlantic forest. Biol J Linn Soc. 2011; 103: 801-820.

98. Dantas G, Sari E, Cabanne G, Pessoa R, Marini M, Miyaki C et al. Population genetic structure of the Atlantic Forest endemic Conopophaga lineata (Passeriformes: Conopophagidae) reveals a contact zone in the Atlantic Forest. J Ornithol. 2014; 156: 85-99.

99. Cabanne G, Campagna L, Trujillo-Arias N, Naoki K, Gómez I, Miyaki C et al. Phylogeographic variation within the Buff-browed Foliage-gleaner (Aves: Furnariidae: Syndactyla rufosuperciliata) supports an Andean-Atlantic forests connection via the Cerrado. Mol Phylogenetics Evol. 2019; 133: 198-213. 


\section{Supporting information captions}

887 S1 Table - Captures.

888

889

890 Trends Ecol Evol. 2002; 17: 520-527.

$$
\text { S2 Table - Genetic samples. }
$$

S3 Table - Live decoys.

S4 Table - Health tests.

100. Edmands S. Does parental divergence predict reproductive compatibility?.

101. Frankham R, Ballou J, Eldridge M, Lacy R, Ralls K, Dudash M et al. Predicting the Probability of Outbreeding Depression. Conserv Biol. 2011; 25: 465-475.

102. Magroski LM, Pessoa AN, Lucena WG, Loures-Ribeiro A, Araújo CB. Where to release birds seized from illegal traffic? The value of vocal analyses and ecological niche modeling. Perspect Ecol Conserv. 2017; 15: 91-101. 


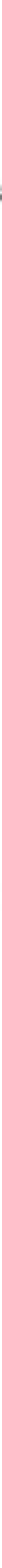


A.



B.

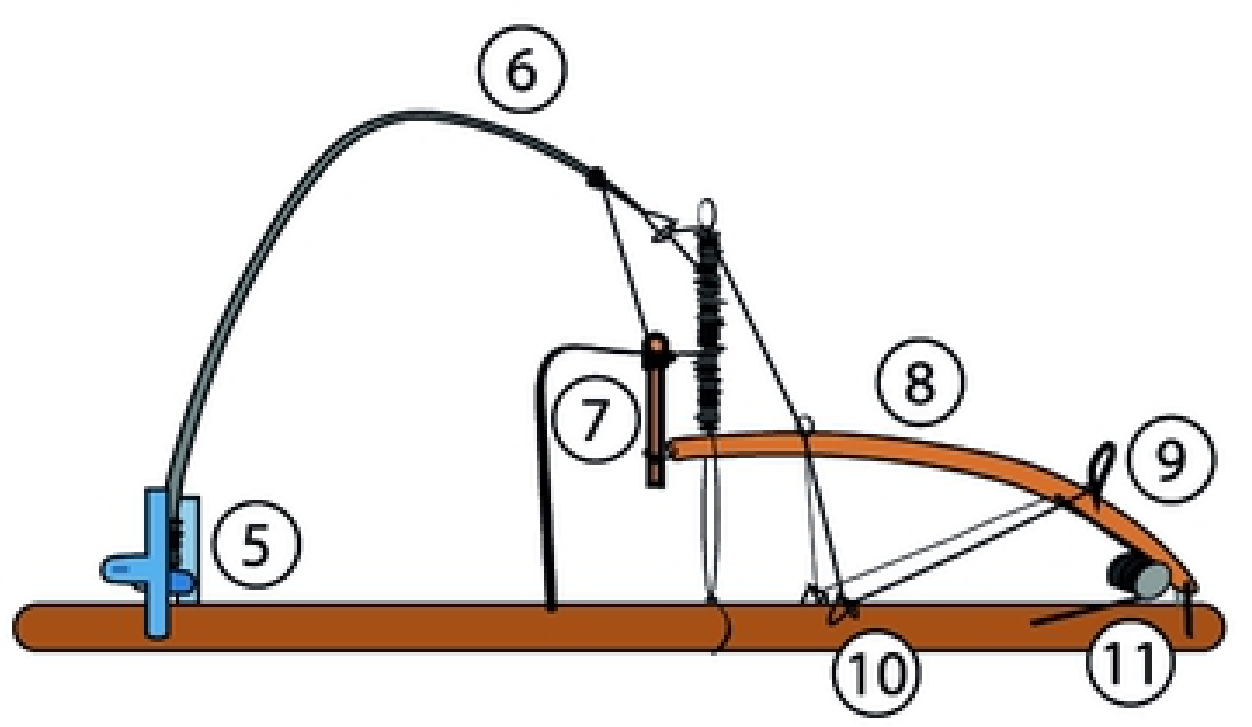

C.



Figure 2 


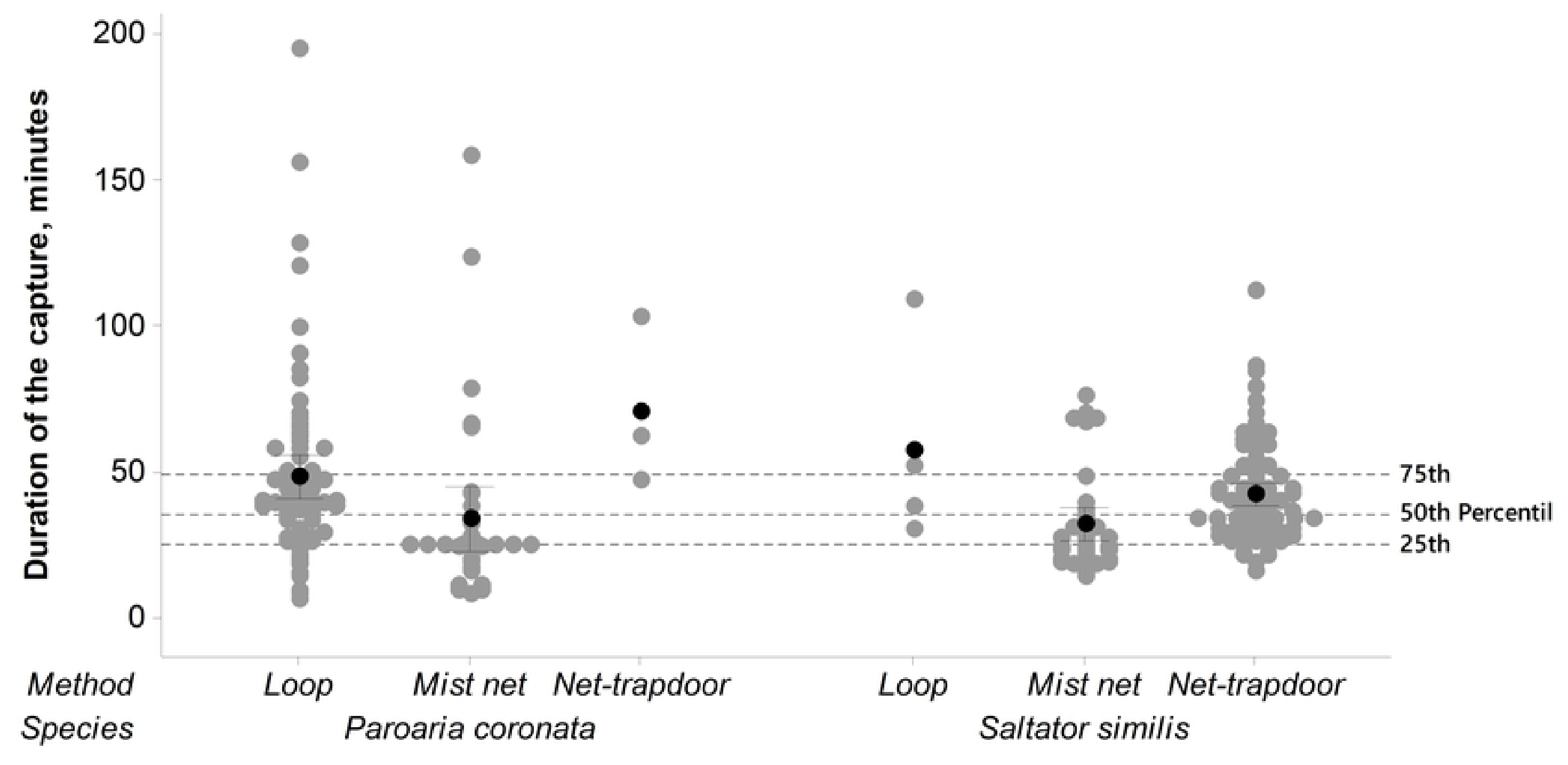

Figure 3 
bioRxiv preprint doi: https://doi.org/10.1101/2020.03.10.985473; this version posted March 10, 2020. The copyright holder for this preprint


daylight hours



- Saltator similis

- Paroaria coronata

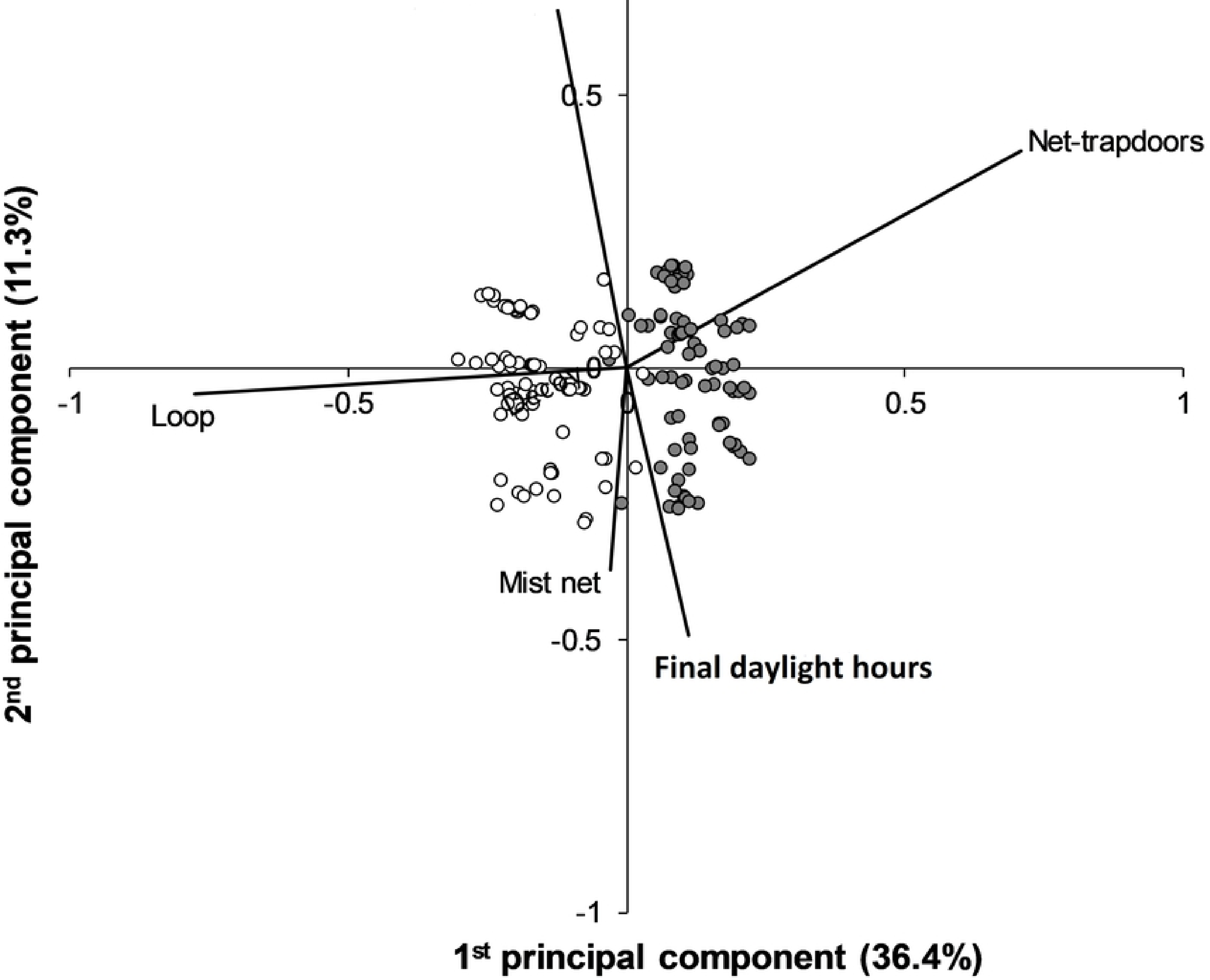

Figure 4 


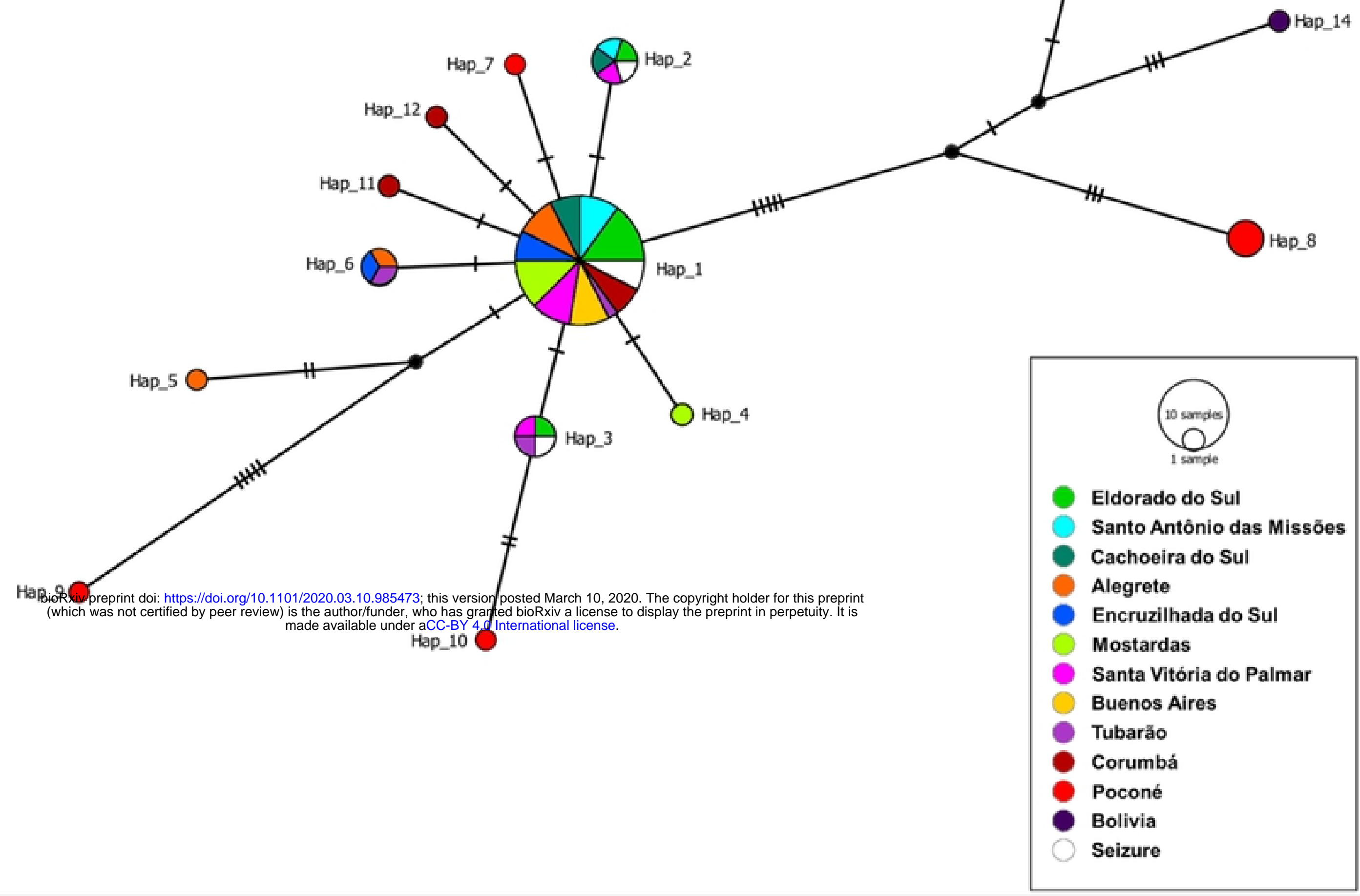

B

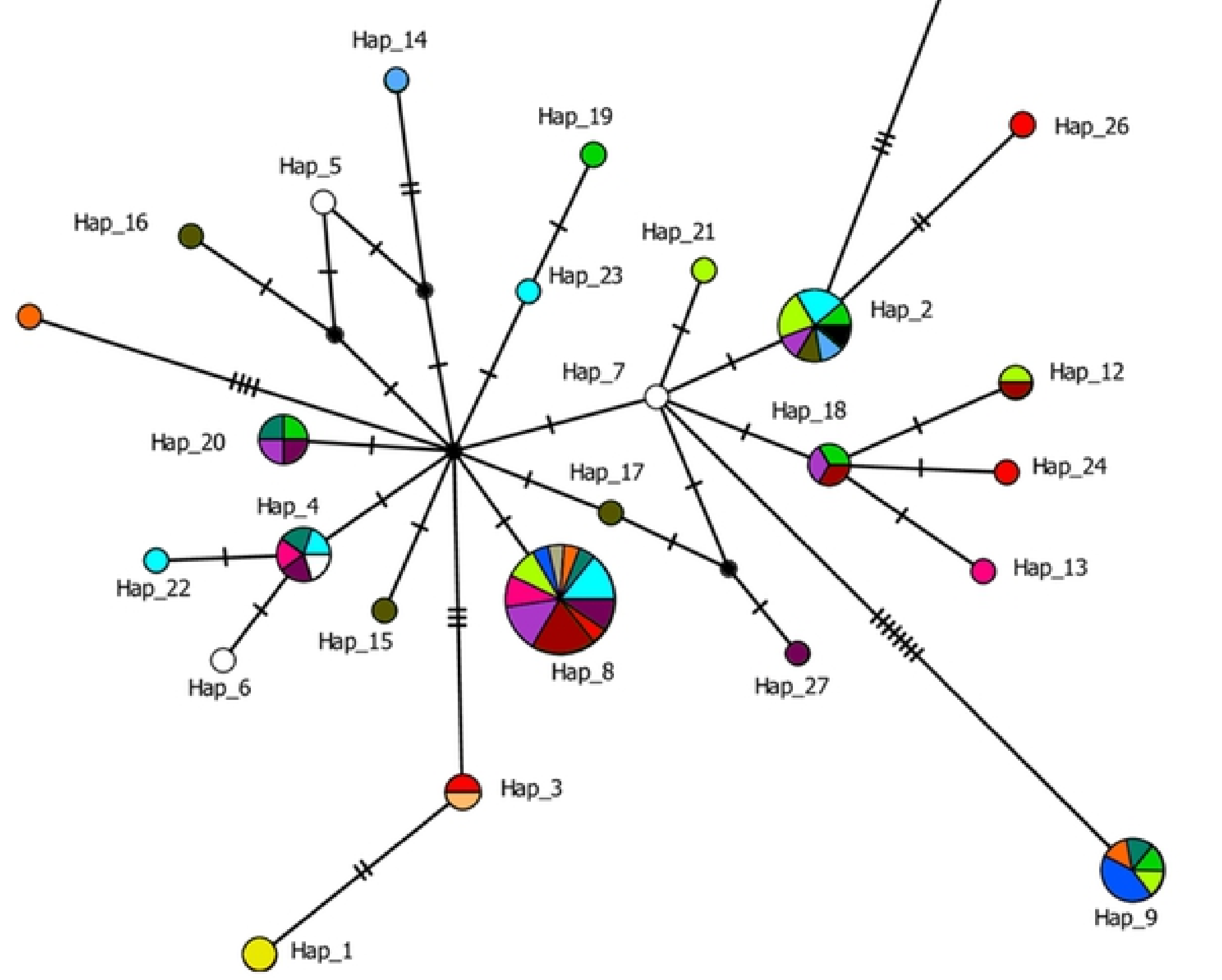

\begin{tabular}{|l|}
\hline Eldorado do Sul \\
Santo Antônio das Missōes \\
Cachoeira do Sul \\
Alegrete \\
Rosário do Sul \\
Encruzilhada do Sul \\
Mostardas \\
Barra do Ribeiro \\
Rio Grande \\
FLONA SFP \\
Rio dos Cedros \\
Foz do Iguaçu \\
Serra do Caparaó \\
Juiz de Fora \\
Boraceia \\
Mato Grosso \\
Corrientes \\
Seizure
\end{tabular}

Figure 5 

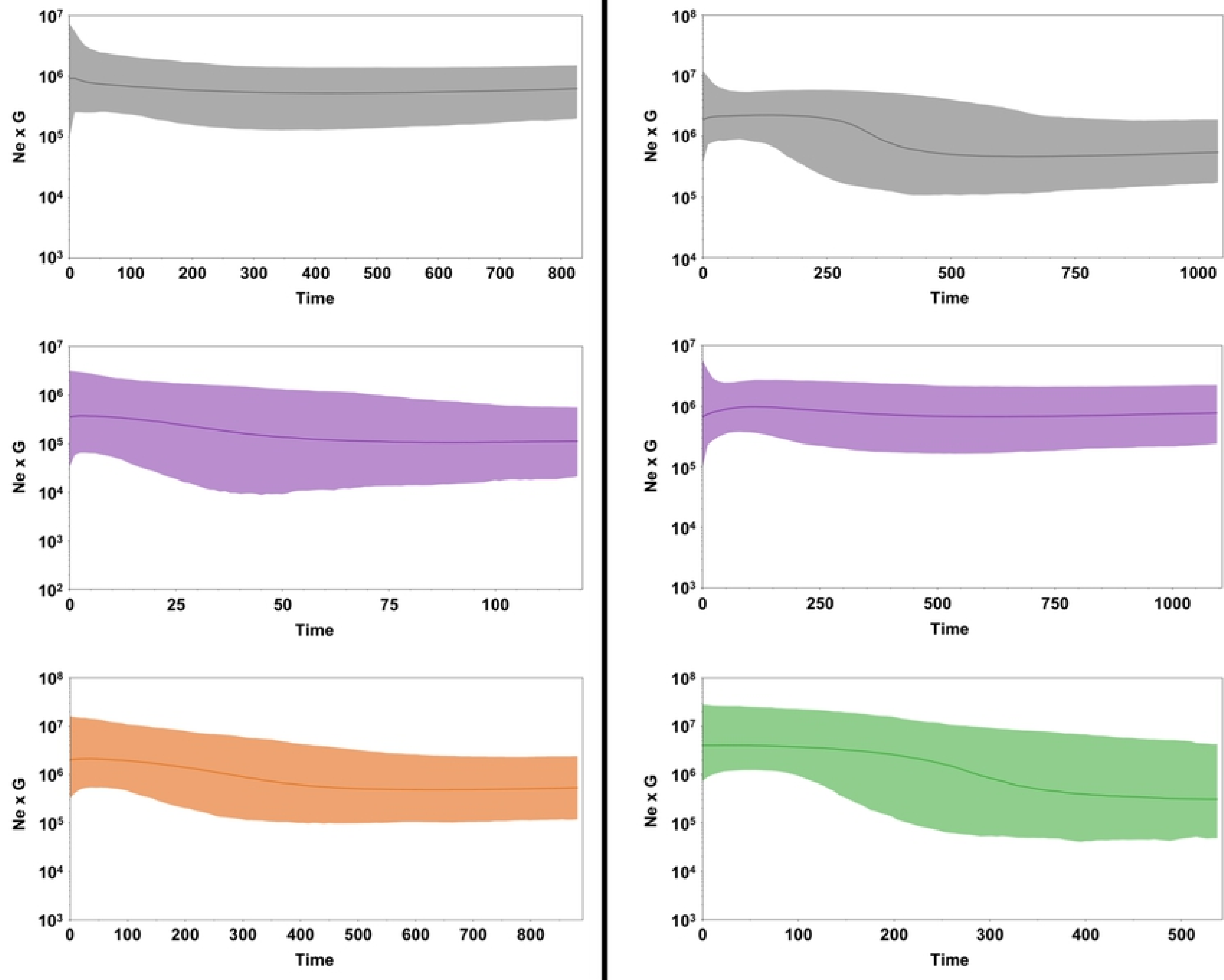

\section{Figure 6}

